\title{
ENDOTHELIAL FUNCTION IN PATIENTS WITH COPD AND CARDIOVASCULAR DISEASE (REVIEW)
}

\author{
Ashcheulova T.V., Gerasimchuk N.N., Kompaniiets K.N., Honchar O.V. \\ Kharkiv National Medical University, Ukraine \\ https://doi.org/10.35339/ic.8.3.144-151
}

\begin{abstract}
Cardiovascular pathology is one of the frequent comorbidities in patients with chronic obstructive pulmonary disease, due to both genetic predisposition and common risk factors (smoking, senile age, male gender, sedentary lifestyle, obesity). The article shows that development of endothelial dysfunction is one of the earliest phases of pathogenesis in this setting. Endothelial dysfunction mechanisms are defined and characterized, including imbalance of vasoconstricting and vasodilating agents with the emergence of "vicious circles" that violate hematovascular homeostasis. The role of nitric oxide, endothelin-1, intercellular adhesion molecule-1 (ICAM-1) in the development of endothelial dysfunction in COPD patients is discussed. The article defines the concept of oxidative stress, the most potent oxidants and mechanisms of their damaging effect are listed. A particular attention is paid to 8-isoprostane as a golden standard in assessment of oxidative stress in patients with COPD. Keywords: chronic obstructive pulmonary disease, hypertension, coronary artery disease, heart failure, nitric oxide, endothelin-1, intercellular adhesion molecule-1, 8-isoprostane.
\end{abstract}

\section{Background}

Chronic obstructive pulmonary disease (COPD) is a medically, socially and economically relevant problem, both in Ukraine and worldwide, leading to limitation of exercise capacity and ranking third among causes of disability after coronary disease (CAD) and hypertension [1-3]. According to the World Health Organization (WHO), roughly every 10 seconds one person dies due to COPD. Currently, more than 210 million people suffer from this disease and by 2030 , COPD trends to become the third leading cause of death in the world [2]. COPD is currently the 4th cause of death, which is primarily due to the high prevalence of smoking among both men and women. It is only surpassed by cardiovascular diseases, infectious diseases (including HIV infection/AIDS) and cancer [4].

According to the WHO estimates, about one third of the world's adult population are smokers. In our country, $58 \%$ of men and $14 \%$ of women

\footnotetext{
Corresponding Author:

Tatiana Ashcheulova MD, PhD, Professor, Head of the Department of Internal Medicine Propedeutics No 1, Basis of Bioethics and Biosafety, Kharkiv National Medical University, Ukraine. E-mail: tatiana.ashcheulova@gmail.com
}

consider themselves to be smokers. The prevalence of tobacco smoking among adolescents is impressive, reaching $50 \%$ by the age of $13-$ 16 years. According to the British research company ERC, Ukraine ranks second in the world in terms of the number of cigarettes smoked per person per year. On average, a Ukrainian smokes 2,500 cigarettes a year, or seven a day [5]. More than $90 \%$ of COPD deaths occur in low- and middle-income countries.

The modern concept of COPD endorsed by the WHO experts emphasizes that severity and prognosis of COPD are often determined by extrapulmonary manifestations of concomitant diseases. This position was reflected in the Global Strategy for the Diagnosis, Treatment and Prevention of COPD (GOLD), 2011 [6].

Most patients with COPD have multiple concomitant diseases. A five-year follow-up of patients with COPD has shown that the risk of death increases not only in proportion to the severity of bronchial obstruction, but also with an increase in the number of concomitant diseases (from 1 to 3) [7].

COPD is accompanied by systemic manifestations, in particular, a significant increase in the incidence of cardiovascular diseases. In addition, 
it is cardiovascular complications that are the main cause of death in patients at the initial stages of COPD. The high frequency of the combination of COPD and cardiovascular pathology is due to genetic predisposition and common risk factors: smoking, senile age, male gender, sedentary lifestyle, obesity, obstructive sleep apnea/hypopnea, secondary hyperaldosteronism, as well as hypertensive effect of a number of drugs used for the treatment of patients with COPD (corticosteroids, beta-2 agonists, etc.) Hypertension, CAD (including myocardial infarction and angina pectoris), cardiac arrhythmias and heart failure (HF) are most common in patients with COPD [8].

The comorbidity of COPD and cardiovascular pathology is driven by a combination of complex multi-stage pathogenetic processes, among which it is difficult to single out the leading factor. Recent studies [9] emphasize the importance of the concept of comorbidity, which implies the formation of relationships and interactions between co-existing diseases, as well as presence of common pathogenetic mechanisms, such as chronic low grade inflammation, oxidative stress, and endothelial dysfunction.

The purpose of this review was to highlight the pathogenetic features of endothelial dysfunction in patients with comorbid course of chronic obstructive pulmonary disease and cardiovascular pathology.

Large epidemiological studies have demonstrated that the leading cause of mortality in patients with COPD and bronchial asthma (BA) is not respiratory failure, as it has been traditionally believed, but cardiovascular events. The severity of the course and prognosis in COPD and BA is determined by the involvement of heart and blood vessels in the pathological process [10], which can lead to development of concomitant cardiovascular pathology. At the annual ERS congress in 2009, J. Feary and N. Barnes from the UK presented the results of the Health Improvement Network, a computer database that unites more than 5 million case histories: - COPD patients are 5 times more likely to be diagnosed with cardiovascular diseases (CVD); - in the 3545 years subgroup, patients with COPD have a 7.6 times higher risk of developing concomitant CVD; - in young patients with COPD, the risk of developing myocardial infarction increases 12-fold [11].

Endothelial dysfunction is a vascular complication of BA and COPD, which, in turn, aggravates the growing respiratory failure, hypoxemia and tissue hypoxia [12]. In this regard, the func- tional state of the endothelium at different periods of the disease is the subject of active study.

To date, more and more data are accumulating that not only local inflammation in the bronchi, but also persistent systemic inflammation, typical for patients with COPD, makes a significant contribution to the development and progression of endothelial dysfunction, atherosclerosis and CVD in patients with broncho-obstructive pathology, determining the interest to this problem.

8-isoprostane as the gold standard for assessing oxidative stress in patients with COPD

The main role in the mechanisms of development of endothelial dysfunction is played by oxidative stress developing against a background of hypoxia [13], which leads to an increase in the production of powerful vasoconstrictors, cytokines and tumor necrosis factor- $\alpha$ (TNF- $\alpha)$. For today, the term "oxidative stress" (OS) is understood as a state in which the amount of free radicals generated in the body significantly exceeds the capacity of endogenous antioxidant systems that ensure their elimination [14]. OS is a common pathway leading to damaging of the vascular endothelium. The disturbance of the equilibrium between synthesis and elimination of reactive oxygen species (ROS) such as (O2-) and (H2O2) affects the homeostasis of cellular oxidative stress, playing an important role in the development of cardiovascular disease [14]. Uncontrolled generation of ROS and their derivatives causes damage to proteins, nucleic acids, enzymes and biological membranes, which may lead to cellular death. OS might also lead to the appearance of cellular mutations and malignant transformation [15]. Toxic components of cigarette smoke can also induce OS, leading to disruption of the functional activity of the endothelium.

8 -iso-PgF2 $\alpha$ (8-isoprostane) is considered to be one of the most specific biological markers that allows estimation of the level of free radicals production with a sufficient degree of accuracy, reliability, and reproducibility. 8-isoprostane is a metabolic product in the reactions of peroxidation of arachidonic acid, isomeric prostaglandin F2, and its amount is directly proportional to the level of free radicals formed. Determination of the level of 8-isoprostane serves as the gold standard for in vivo oxidative stress evaluation [16].

8-isoprostane reflects the cellular effects of OS and, therefore, the inflammatory process in the airways. In recent years, there has been an increasing interest in the study of the lungs by means of non-invasive methods, including measurement of biomarkers in exhaled air and 
exhaled breath condensate (EBC) [17]. These methods are safe, do not affect lung function and the level of exhaled mediators [18], which allows their use as epidemiological methods for studying pathological processes (OS and inflammation) in respiratory diseases.

The concentration of 8-isoprostane in the $\mathrm{EBC}$ was increased in patients with remission of COPD compared with healthy non-smokers [19, 20]. Also, the level of 8-isoprostane in EBC was increased in healthy smokers [20] and patients with exacerbation of COPD [19, 21, 22]. Montuschi P. et al. showed that the levels of 8-isoprostane in patients with COPD, both smokers and non-smokers, were 1.8 times higher than in healthy smokers. In healthy non-smokers, its concentration was 2.2 times lower than in healthy smokers. There were no correlations between the level of 8-isoprostane and forced expiratory volume in 1 second (FEV1), smoking experience, cellular composition of sputum or severity of dyspnea in patients with COPD $[19,20]$. However, a 2-fold increase in 8-isoprostane level in EBC compared to healthy people was reported in patients with mild course of bronchial asthma, and in severe course, its level was 3 times higher than in patients with mild bronchial asthma, regardless of inhalation treatment received. After treatment, its concentration decreased [23, 24].

Pathogenetic features of endothelial dysfunction in patients with chronic obstructive pulmonary disease and cardiovascular pathology

Currently, the prominent role of endothelium and nitric oxide in the genesis of cardiovascular complications of COPD has been proven. The unique position of endothelial cells at the border between circulating blood and tissues, and in the case of the lungs, the air environment of the alveolar space and blood, makes them not only the most important, but also the most vulnerable to various pathogenic influences that can cause damage to endothelial cells, thereby contributing to the development of endothelial dysfunction (ED) [25]. ED is based on structural (apoptosis and desquamation of endothelial cells) and functional (imbalance between biologically active substances produced in the endothelium) changes. Endothelium forms a thin semi-permeable membrane lining the heart and blood vessels from the inside, continuously producing a huge amount of biologically active substances (BAS). Hence, the complex of endothelial cells may be considered a giant paracrine organ distributed throughout the human body [26]. Endothelial cells produce
BAS that take part in the regulation of vascular tone, synthesis of growth factors and mediators of nonspecific inflammation. In healthy individuals, the effect of endothelial BAS is in dynamic equilibrium. The main role of the endothelium is associated with dilatation of the vascular bed, which provides the peripheral muscles and internal organs with adequate blood supply [27]. Under physiological conditions, secretion of vasodilating substances predominates. Nitric oxide (NO), which controls the basal tone of arterioles and, as a consequence, participates in blood pressure (BP) control, is the main endothelium-derived vasodilating factor. If the ability of endothelial cells to produce vasodilating substances decreases, and the formation of vasoconstrictors persists or increases, the so-called ED is formed - a disturbance of the equilibrium of oppositely acting BAS that violates hematovascular homeostasis. Endothelium is a dynamic system that maintains the normal properties of circulating blood by inhibiting hypercoagulation and preventing leukocyte adhesion [28].

In the pathogenesis of COPD, the main factor in the development of ED is a decrease in NO synthesis with preserved or increased secretion of vasoconstrictors (endothelin-1, thromboxane, angiotensin II), as well as cytokines and tumor necrosis factor- $\alpha$ (TNF- $\alpha)$ that further suppress nitric oxide production [28], which impairs endothelium-dependent vasorelaxation and leads to degradation and adverse changes in vascular cytoarchitectonics.

Many studies have assessed the diagnostic value of plasma ED biomarkers, since this is a simple and objective method that provides information both on normal physiological processes and in pathology. Taking into account the fact that the levels of circulating plasma BAS depend not only on the severity of ED but also on other factors (concomitant pathology, immune diseases, chronic infections), the results being significant in a separate study may not necessarily reflect the picture at the populational level. Therefore, an ED biomarker should optimally have a predictive role in relation to the cardiovascular risk. The results of earlier studies [29] showed that E- and P-selectins, endothelin-1, von Willebrand factor, cell adhesion molecules, and thrombomodulin have a significant prognostic value in this context.

A significant increase in the blood endothelin-1 (ET-1) level has been reported in patients with uncomplicated hypertension. In patients with stage 2 and 3 hypertension, the level of ET- 1 and its precursor increases 10 -fold [30]. ET-1 is a 
large bicyclic polypeptide synthesized in the vascular endothelium, bronchial epithelium and in alveolar macrophages. Its main function is to activate vasoconstriction, particularly in small vessels. Another function of ET-1 is the ability to influence platelet adhesion, which contributes to formation of microthrombosis [31]. In hypoxia, the level of ET-1 in the blood increases. Especially high plasma levels are detected in COPD exacerbation. In patients with COPD with hypoxemia, the level of ET-1 in the arterial blood is higher compared to those without hypoxemia [32]. High levels of ET-1 contribute to the further progression of ED, thereby aggravating the course of the disease [33]. A significant association has been shown between the level of ET-1 and hemodynamic parameters of pulmonary circulation. Shao D. et al. have shown the correlation between ET-1 levels with pulmonary artery pressures and pulmonary vascular resistance [34]. Presence of high ET-1 levels in patients with COPD contributes to adverse cardiovascular and pulmonary remodeling with dilation of the cardiac chambers and formation of a chronic cor pulmonale [35-37]. ET-1 induces prolonged vasoconstriction, hypertrophy of the smooth myocytes and endothelial remodeling affecting arterial elasticity [38]. Thus, it can be assumed that impaired endothelial function triggers the process of structural and anatomical changes in the vascular wall and increases the arterial stiffness [39].

The interaction of leukocytes with the endothelium occurs through special adhesive molecules, which are present on both endothelial cells and leukocytes. Selectins (P, E, L) present a class of adhesion molecules. P- and E-selectins are expressed by the endothelium. An increase in the endothelial adhesiveness plays an important role in the pathogenesis of ED in inflammation, atherosclerosis, septic shock, and other pathological processes. P-selectin is accumulated in the endothelium and released from it during stimulation. Adhesion molecules may be getting into the bloodstream not only with stimulation of the endothelium, but also in its activation and damage, as evidenced by data provided by E. Oelsner et al. (2013), showing high levels of endothelial dysfunction biomarkers (endothelin-1 and adhesive molecules (P-selectin and ICAM-1)) in COPD patients with their level correlating to the severity of bronchial obstruction [40]. This data is also confirmed by the results of the Framingham study, in which patients with COPD had high levels of inflammation markers: CRP, ICAM-1 and P-selectin, the activity of which had an inverse rela- tionship with the value of forced expiratory volume in 1 second (FEV 1) [41]. A study by J. Zhonghua et al. has also shown an increase of P-selectin levels in patients with COPD, which was more prominent during exacerbations [42]. As for the previously mentioned intercellular adhesion molecule-1 (ICAM-1), it belongs to the family of immunoglobulins and serves as a functional ligand for the leukocyte integrin LFA-1 (Lymphocyte Function-Associated Antigen-1). Adhesion of monocytes to activated endothelial cells due to overexpression of ICAM-1 on their surface is considered the earliest stage of endothelial damage. Inhibition of adhesion molecules expression, in particular ICAM-1, prevents the accumulation of inflammatory agents in the vascular wall, which reduces their ability to cause endothelial damage that is characteristic of COPD [43] and cardiovascular pathology [44].

The leading role in reduction of the endothelium-dependent vasodilation (EDVD) in patients with COPD is played by intracellular OS, and smoking is the most significant exogenous factor in its formation. Free radical oxidation significantly reduces NO production by endothelial cells [45], which is manifested by suppression of NO synthase expression by endothelial cells and stimulation of adhesion molecules expression, followed by increased adhesion of leukocytes to the luminal surface of the vascular wall [46]. It has been shown that cigarette smoking leads to impaired vascular reactivity, namely, weakening of endothelium-dependent vasodilation [47]. It was found that an increase in smoking intensity was characterized by a progressive decrease in EDVD, as well as development of not only endothelial damage, but an adverse remodeling of deeper layers of vascular wall in smoking COPD [48].

To date, the features of the formation and clinical significance of increased arterial stiffness in patients with CVD (atherosclerosis, hypertension, ischemic heart disease) are most fully studied [49]. Perhaps, it is the increased arterial stiffness and endothelial dysfunction that is the link between COPD and CVD.

Features of the course of hypertension, coronary artery disease, heart failure in COPD

Previous studies have shown that the patients with a comorbid course of COPD and CVD have distinct clinical features compared to isolated course of these diseases.

The patients with hypertension and COPD are characterized by a higher resting heart rate (HR) [50]; more frequent target organs damage, including renal failure, and a higher risk of 
cardiovascular complications when compared with hypertensive patients without COPD at the same blood pressure (BP); hypertension in patients with COPD is characterized by earlier manifestation and higher BP values [51]. In patients with COPD, significant changes in the course of hypertension are related mainly to the night period: disturbance of the circadian rhythm of blood pressure with insufficient night dip; a more significant increase in DBP and an increase in the morning surge. All patients showed an increase in blood pressure variability [52]. It follows that such patients need to optimize BP control in the evening and night hours.

In a Spanish study evaluating airflow restriction using spirometry in patients with/without CVD in general population and among hospitalized CAD patients, airflow restriction was found in $19.2 \%, 17.5 \%$ and $33.6 \%$, respectively [53]. The highest prevalence of COPD was observed among patients with CAD. Therefore, it would be beneficial for all CVD patients to undergo spirometry [54]. The patients with established CAD and COPD had more severe atherosclerosis vs those without COPD [55]. Another study showed that patients with COPD had more atherosclerotic lesions found in PCI compared with patients without COPD, and these patients had a higher mortality rate $[56,57]$.

The PREMIER study, which evaluated the course of myocardial infarction, showed that in patients with COPD, the risk of mortality and readmission was twice as high and the quality of life was lower $[58,59]$. A large retrospective observational study of Swedish COPD patients in primary care has shown that coexisting heart failure, stroke and myocardial infarction were the strongest predictors of death, highlighting the importance of early detection and treatment of comorbidities. A reduced risk of death was also found to be associated with the use of inhaled corticosteroids, beta-blockers and aspirin, and an increased risk associated with the use of longacting muscarinic antagonists and $\mathrm{N}$-acetylcysteine [60].

\section{Conclusions}

The development of cardiovascular diseases against a background of chronic obstructive pulmonary disease may be considered to some extent natural. The evidence shows that endothelial dysfunction is one of the main components in the pathogenesis of comorbid course of chronic obstructive pulmonary disease with hypertension, coronary heart disease. Assessment of the endothelial function may be of importance for expanding understanding of pathogenesis in many conditions and clinically for predicting the development of complications. This will make it possible to use drug therapy in the treatment of such patients, including the drugs that have a positive effect on the state of the endothelium.

\section{Declarations}

\section{Statement of Ethics}

The authors have no ethical conflicts to disclosure.

\section{Consent for publication}

All authors give their consent to publication.

\section{Disclosure Statement}

The authors have no potential conflicts of interest to disclosure.

\section{Funding Sources}

There are no external sources of funding Data Transparency

The data can be requested from the authors.

\section{References}

1. Lopez, A. D., Shibuya, K., Rao, C., Mathers, C. D., Hansell, A. L., Held, L. S., ... \& Buist, S. (2006). Chronic obstructive pulmonary disease: current burden and future projections. European Respiratory Journal, 27(2), 397-412. doi.org/10.1183/09031936.06.00025805

2. Mathers, C. D., \& Loncar, D. (2006). Projections of global mortality and burden of disease from 2002 to 2030. PLoS medicine, 3(11), e442. doi.org/10.1371/journal.pmed.0030442

3. Trupin, L., Earnest, G., San Pedro, M., Balmes, J. R., Eisner, M. D., Yelin, E., ... \& Blanc, P. D. (2003). The occupational burden of chronic obstructive pulmonary disease. European Respiratory Journal, 22(3), 462-469. doi.org/10.1183/09031936.03.00094203

4. Dahl, R., Chung, K. F., Buhl, R., Magnussen, H., Nonikov, V., Jack, D., ... \& Kramer, B. (2010). Efficacy of a new once-daily long-acting inhaled $\beta 2$-agonist indacaterol versus twice-daily formoterol in COPD. Thorax, 65(6), 473-479. doi.org/10.1136/thx.2009.125435

5. Feshhenko, Ju. I. (2009). HOZL v Ukraine: problemy i puti reshenija. Zdorov'ja Ukraïni, 9(1), 3-4 (in Russian).

6. Global'naja strategija diagnostiki, lechenija i profilaktiki HOBL. Peresmotr 2011 g. Per. s angl. / pod red. A.S. Belevskogo. M.: Rossijskoe respiratornoe obshhestvo, 2012. 80s. [Global Initiative for Chronic Obstructive Lung Diseases. Global Strategy for Diagnosis, Management and Prevention for 
Chronic Obstructive Lung Diseases (Revised 2011). Rossiyskoe Respiratornoye Obschestvo Publ., 2012 (in Russian)].

7. Mannino, D. M., Thorn, D., Swensen, A., \& Holguin, F. (2008). Prevalence and outcomes of diabetes, hypertension and cardiovascular disease in COPD. European Respiratory Journal, 32(4), 962969. doi.org/10.1183/09031936.00012408

8. Ovcharenko, S. I. (2018). Serdechno-sosudistaja patologija u bol'nyh hronicheskoj obstruktivnoj bolezn'ju legkih: kak my lechim?. RMZh, 26(10-1), 36-39 [Ovcharenko, S.I. (2018). Cardiovascular pathology in patients with chronic obstructive pulmonary disease: how do we treat it? RMJ. 10 (I), 3639] (in Russian).

9. Babak, O. Ja., Shaposhnikova, Ju. N., \& Nemcova, V. D. (2004). Arterial'naja gipertenzija i ishemicheskaja bolezn' serdca-jendotelial'naja disfunkcija: sovremennoe sostojanie voprosa. Ukrainskij terapevticheskij zhurnal, (1), 14-22.

10. Chuchalin, A. G. (2008). Hronicheskaja obstruktivnaja bolezn' legkih i soputstvujushhie zabolevanija. Pul'monologija, (2), 5-14 (in Russian).

11. Feary. J, \& Branes N. (2009). Abstract, ERS, 19 Annual Congress. sept.13. P. 962.

12. Brodskaja, T. A., Nevzorova, V. A., Gelcer, B. I., \& Motkina, E. V. (2007). Jendotelial'naja disfunkcija i bolezni organov dyhanija. Terapevticheskij arhiv, 79(3), 76-84 (in Russian).

13. Birben, E., Sahiner, U. M., Sackesen, C., Erzurum, S., \& Kalayci, O. (2012). Oxidative stress and antioxidant defense. World Allergy Organization Journal, 5(1), 9-19.doi.org/10.1097/wox.0b013e3182439613

14. Kovaljova, O. N., Ashcheulova, T. V., Gerasimchuk, N. N., \& Safargalina-Kornilova, N. A. (2015). Rol'oksidativnogo stressa v stanovlenii i progressirovanii gipertonicheskoj bolezni [Role of oxidative stress in the formation and progression of hypertensive disease]. Nauchnye Vedomosti Belgorodskogo Gosudarstvennogo Universiteta Medicina Farmacija, Aktual'nye problemy mediciny, 29(4(201)), 5-10 (in Russian).

15. Rahman, I., \& Adcock, I. M. (2006). Oxidative stress and redox regulation of lung inflammation in COPD. European respiratory journal, 28(1), 219-242. doi.org/10.1183/09031936.06.00053805

16. Yin, H. (2008). New techniques to detect oxidative stress markers: mass spectrometry-based methods to detect isoprostanes as the gold standard for oxidative stress in vivo. Biofactors, 34(2), 109124. doi.org/10.1002/biof.5520340203

17. Herasymchuk, N. (2018). 8-isoprostane as the main marker of oxidative stress. Zaporozhye medical journal. Volume 20. No. 6 (11), 2018, - 853-859. doi.org/10.14739/2310-1210.2018.6.146780

18. Horvath, I., Hunt, J., \& Barnes, P. J. (2005). Exhaled breath condensate: methodological recommendations and unresolved questions. European Respiratory Journal,26(3), 523-548. doi.org/ 10.1183/09031936.05.00029705

19. Kostikas, K., Papatheodorou, G., Psathakis, K., Panagou, P., \& Loukides, S. (2003). Oxidative stress in expired breath condensate of patients with COPD. Chest, 124(4), 1373-1380. doi.org/10.1378/ chest.124.4.1373

20. Montuschi, P., Collins, J. V., Ciabattoni, G., Lazzeri, N., Corradi, M., Kharitonov, S. A., \& Barnes, P. J. (2000). Exhaled 8-isoprostane as an in vivo biomarker of lung oxidative stress in patients with COPD and healthy smokers. American journal of respiratory and critical care medicine, 162(3), 1175-1177.doi.org/ 10.1164/ajrccm.162.3.2001063

21. Antczak, A., Ciebiada, M., Pietras, T., Piotrowski, W. J., Kurmanowska, Z., \& Gorski, P. (2012). Exhaled eicosanoids and biomarkers of oxidative stress in exacerbation of chronic obstructive pulmonary disease. Archives of medical science: AMS, 8(2), 277-285. oi.org/10.5114/aoms.2012.28555

22. Biernacki, W. A., Kharitonov, S. A., \& Barnes, P. J. (2003). Increased leukotriene B4 and 8 -isoprostane in exhaled breath condensate of patients with exacerbations of COPD. Thorax, 58(4), 294-298. doi.org/10.1136/thorax.58.4.294

23. Anaev, Je. H., Kushaeva, M. Je., \& Kurova, V. S. (2012). Znachenie proteomnogo analiza kondensata vydyhaemogo vozduha pri diagnostike HOBL i pnevmonii. Pul'monologija. 5, 5-9.

24. Ko, F. W., Lau, C. Y., Leung, T. F., Wong, G. W., Lam, C. W., \& Hui, D. S. (2006). Exhaled breath condensate levels of 8-isoprostane, growth related oncogene $\alpha$ and monocyte chemoattractant protein-1 in patients with chronic obstructive pulmonary disease. Respiratory medicine, 100(4), 630638. doi.org/10.1016/j.rmed.2005.08.009

25. Wanner, A., \& Mendes, E. S. (2010). Airway endothelial dysfunction in asthma and chronic obstructive pulmonary disease: a challenge for future research. American journal of respiratory and critical care medicine, 182(11), 1344-1351. doi.org/10.1164/rccm.201001-0038pp 
26. Malaja, L. T., Korzh, A. N., \& Balkovaja, L. B. (2000). Jendotelial'naja disfunkcija pri patologii serdechno-sosudistoj sistemy. Har'kov: Torsing, 432 (in Russian).

27. Hall C. (2001). The value of natriuretic peptides for the management of heart failure: current state of play. European Journal of Heart Failure. 3(4): 395-397. doi.org/10.1016/s1388-9842(01)00151-9

28. Ashheulova, T. V., Kovaleva, O. N., Gerasimchuk, N. N., \& Safargalina-Kornilova, N. A. (2016). Funkcional'noe sostojanie jendotelija i aktivnost' provospalitel'nyh citokinov u bol'nyh gipertonicheskoj bolezn'ju, associirovannoj s ozhireniem [Endothelial function and activity of proinflammatory cytokines in patients with hypertension associated with obesity]. Nauchnye Vedomosti Belgorodskogo Gosudarstvennogo Universiteta Medicina Farmacija, Aktual'nye problemy mediciny, 34(12 (233)), 5-14 (in Russian).

29. Ribeiro, F., Alves, A. J., Teixeira, M., Ribeiro, V., Duarte, J. A., \& Oliveira, J. (2009). Endothelial function and atherosclerosis: circulatory markers with clinical usefulness. Revista portuguesa de cardiologia: orgao oficial da Sociedade Portuguesa de Cardiologia= Portuguese journal of cardiology: an official journal of the Portuguese Society of Cardiology, 28(10), 1121-1151.

30. Lapshina, L. A., Molodan, V. I., Shevchenko, O. S., \& Nemcova, V. D. (2001). Jendotelial'naja disfunkcija pri nachal'nyh stadijah arterial'noj gipertenzii i sposoby ee nemedikamentoznoj korrekcii. Ukrainskij terapevticheskij zhurnal, 3(4), 39 (in Russian).

31. Danilenko, S. A., \& Landyshev, Ju. S. (2010). Mikrogemocirkuljatornye narushenija v slizistoj obolochke bronhov pri hronicheskoj obstruktivnoj bolezni legkih. Regionarnoe krovoobrashhenie i mikrocirkuljacija, 9(1), 38-41 (in Russian).

32. Van Suylen, R. J., Smits, J. F., \& Daemen, M. J. (1998). Pulmonary artery remodeling differs in hypoxia-and monocrotaline-induced pulmonary hypertension. American journal of respiratory and critical care medicine, 157(5), 1423-1428 (in Russian). doi.org/10.1164/ajrccm.157.5.9709050

33. Bakakos, P., Patentalakis, G., \& Papi, A. (2016). Vascular Biomarkers in Asthma and COPD. Curr Top Med Chem. 16(14), 1599-1609. doi.org/10.2174/1568026616666150930121157

34. Shao, D., Park, J. E., \& Wort, S. J. (2011). The role of endothelin-1 in the pathogenesis of pulmonary arterial hypertension. Pharmacological Research, 63(6), 504-511. doi.org/10.1016/ j.phrs.2011.03.003

35. Almagro, P., Cabrera, F. J., Diez, J., Boixeda, R., Ortiz, M. B. A., Murio, C., \& Soriano, J. B. (2012). Comorbidities and Short-term Prognosis in Patients Hospitalized for Acute Exacerbation of COPDComorbidity and Prognosis in COPD Hospitalized Patients The EPOC en Servicios de Medicina Interna (ESMI) Study. Chest Journal, 142(5), 1126-1133. doi.org/10.1378/chest.11-2413

36. Mannino, D. M., \& Sanderson, W. T. (2017). Using big data to reveal chronic respiratory disease mortality patterns and identify potential public health interventions. Jama, 318(12), 1112-1114. doi.org/ 10.1001/jama.2017.11746

37. Ives, S. J., Harris, R. A., Witman, M. A., Fjeldstad, A. S., Garten, R. S., McDaniel, J., ... \& Richardson, R. S. (2014). Vascular dysfunction and chronic obstructive pulmonary disease: the role of redox balance. Hypertension, 63(3), 459-467. doi.org/10.1161/hypertensionaha.113.02255

38. Barnes, P. J., Shapiro, S. D., \& Pauwels, R. A. (2003). Chronic obstructive pulmonary disease: molecular and cellularmechanisms. European Respiratory Journal, 22(4), 672-688. doi.org/10.1183/ 09031936.03.00040703

39. Makarova, M. A., Avdeev, S. N., \& Chuchalin, A. G. (2014). Arterial'naja rigidnost' i jendotelial'naja disfunkcija u pacientov s hronicheskoj obstruktivnoj bolezn'ju legkih: chto pervichno? [Arterial stiffness and endothelial dysfunction in patients with chronic obstructive pulmonary disease: what is primary and secondary?] Pul'monologija, (6), 73-79 (in Russian). doi.org/10.18093/0869-0189-2011-0-6-73-79

40. Oelsner, E.C., Pottinger, T.D., Burkart, K.M., \& Allison, M. (2013). Adhesionmolecules, endothelin1 and lung functioni n seven population-basedcohorts. Biomarkers; 18 (3), 196-203.

41. Walter, R.E., Wilk, J.B., Larson, M.G., \& Vasan RS. (2008). Systemic inflammation and COPD: the Framingham Heart Study. Chest; 133 (1), 19-25.

42. He, Z. J. H., \& Zhi, H. X. Z. (2010). Integrin-associated proteins in blood plasma of patients with acuteexacerbation of chronic obstructive pulmonary disease. Article in Chinese, 33(4), 265-7.

43. Riise, G. C., Larsson, S., Lofdahl, C. G., \& Andersson, B. A. (1994). Circulating cell adhesion molecules in bronchial lavage and serum in COPD patients with chronic bronchitis. European Respiratory Journal, 7(9), 1673-1677. doi.org/10.1183/09031936.94.07091673

44. Pollock, D. M. (2005). Endothelin, angiotensin, and oxidative stress in hypertension. Hypertension, 45(4), 477-480. 
45. Ashheulova, T. V., Zaika, M. V., \& Gerasimchuk, N. N. (2007). Vzaimosvjaz' immunnoj aktivacii i oksidativnogo stressa pri progressirovanii arterial'noj gipertenzii. [The relationship between immune activation and oxidative stress in the progression of arterial hypertension]. Ukrainskij terapevticheskij zhurnal, 2, 12-15 (in Russian).

46. Barua, R. S., Ambrose, J. A., Eales-Reynolds, L. J., DeVoe, M. C., Zervas, J. G., \& Saha, D. C. (2001). Dysfunctional endothelial nitric oxide biosynthesis in healthy smokers with impaired endotheliumdependent vasodilatation. Circulation, 104(16), 1905-1910. doi.org/10.1161/hc4101.097525

47. Butler, R., Morris, A. D., \& Struthers, A. D. (2001). Cigarette smoking in men and vascular responsiveness. British journal of clinical pharmacology, 52(2), 145-149. doi.org/10.1046/j.03065251.2001.01434.x

48. Karoli, N. A., \& Rebrov, A. P. (2004). Vlijanie kurenija na razvitie jendotelial'noj disfunkcii u bol'nyh hronicheskoj obstruktivnoj bolezn'ju legkih. Pul'monologija, 2(14), 70-78.

49. Laurent, S., Katsahian, S., Fassot, C., Tropeano, A. I., Gautier, I., Laloux, B., \& Boutouyrie, P. (2003). Aortic stiffness is an independent predictor of fatal stroke in essential hypertension. Stroke, 34(5), 1203-1206. doi.org/10.1161/01.str.0000065428.03209.64

50. Mahendra, M., Kumar, S., Desai, N., Jayaraj, B. S., \& Mahesh, P. A. (2018). Evaluation for airway obstruction in adult patients with stable ischemic heart disease. Indian heart journal, 70(2), 266271. doi.org/10.1016/j.ihj.2017.08.003.

51. Ratova, L. G., Zykov, K. A., Dolgusheva, Ju. A., Agapova, O. Ju., Nazarov, B. M., \& Chazova, I. E. (2012). Arterial'naja gipertonija i bronhoobstruktivnaja patologija-osobennosti klinicheskoj kartiny. Sistemnye gipertenzii, 9(1), 54-59. [Arterial'naya gipertoniya i bronkhoobstruktivnaya patologiya osobennosti klinicheskoy kartiny] (in Russian). doi.org/10.26442/SG33169

52. Ovcharenko, S., I., Nersesyan, Z., N., \& Morozova, T., E.. (2014). Chronic obstructive pulmonary disease combined with arterial hypertension: efficacy and safety ofthesustained-release indapamide (Arifon ${ }^{\circledR}$ retard) Systemic Hypertension, 11(2).54-58. doi.org/10.26442/sg29026

53. Triest, F. J., Studnicka, M., Franssen, F. M., Vollmer, W. M., Lamprecht, B., Wouters, E. F., ... \& Vanfleteren, L. E. (2019). Airflow obstruction and cardio-metabolic comorbidities. COPD: Journal of Chronic Obstructive Pulmonary Disease, 16(2), 109-117. doi.org/10.1080/15412555.2019.1614550

54. Malo de Molina, R., Aguado, S., Arellano, C., Valle, M., \& Ussetti, P. (2018). Ischemic heart disease during acute exacerbations of COPD. Medical Sciences, 6(4), 83. doi.org/10.3390/medsci6040083

55. Khassawneh, B. Y., Samrah, S. M., Jarrah, M. I., Ibdah, R. K., Ibnian, A. M., Almistarehi, A. W., ... \& Khader, Y. S. (2018). Prevalence of undiagnosed COPD in male patients with coronary artery disease: a cross-sectional study in Jordan. International journal of chronic obstructive pulmonary disease, 13, 2759-2766. doi:10.2147/COPD.S172679 PMCID: PMC6130534.

56. Biscaglia, S., Ruggiero, R., Di Cesare, A., Serenelli, M., \& Ferrari, R. (2019). Angina and chronic obstructive pulmonary disease: facing the perfect storm. European Heart Journal Supplements, 21(Supplement_C), 17-20. doi.org/10.1093/eurheartj/suz042

57. Almagro, P., De la Sierra, A., Acosta, E., Navarro, A., Garcia, M. E., Valdivieso, S., ... \& Agusti, A. (2018). Spirometrically confirmed chronic obstructive pulmonary disease worsens long-term prognosis after percutaneous coronary intervention. American journal of respiratory and critical care medicine, 197(6), 824-826. doi.org/10.1164/rccm.201707-1389le

58. Andersson, C., Hansen, P. W., Steffensen, I. E., Andreasen, C., Weeke, P. E., Kober, L., ... \& Torp-Pedersen, C. (2019). Mortality associated with cardiovascular drugs in patients with chronic obstructive pulmonary disease and right-sided heart failure-A danish nationwide registry-based study. European journal of internal medicine, 63, 56-61. doi.org/10.1016/j.ejim.2019.02.014

59. Bazargan, M., Smith, J. L., Robinson, P., Uyanne, J., Abdulrahoof, R., Chuku, C., \& Assari, S. (2019). Chronic respiratory disease and health-related quality of life of African American older adults in an economically disadvantaged area of Los Angeles. International journal of environmental research and public health, 16(10), 1756. doi.org/10.3390/ijerph16101756

60.Ellingsen, J., Johansson, G., Larsson, K., Lisspers, K., Malinovschi, A., St?llberg, B., ... \& Janson, C. (2020). Impact of Comorbidities and Commonly Used Drugs on Mortality in COPD-Real-World Data from a Primary Care Setting. International journal of chronic obstructive pulmonary disease, 15, 235. doi: 10.2147/COPD.S231296. 